\title{
Fungal Variation during Peanut Paste Storage
}

\author{
Zamblé Bi Irié Abel Boli $\mathbb{D}^{1},{ }^{1}$ Ollo Kambire, ${ }^{2}$ Lessoy Thierry Zoue, ${ }^{3}$ and Rose Koffi Nevry ${ }^{1}$ \\ ${ }^{1}$ Laboratory of Biotechnology and Food Microbiology, Department of Food Science and Technology, Nangui Abrogoua University, \\ 02 BP 801, Abidjan, Côte d'Ivoire \\ ${ }^{2}$ Peleforo Gon Coulibaly University, Department of Biochemistry and Genetics, BP 1328, Korhogo, Côte d'Ivoire \\ ${ }^{3}$ Laboratory of Biotechnology, Department of Biosciences, Felix Houphouët-Boigny University, 22 Bp 582, Abidjan 22, \\ Côte d'Ivoire
}

Correspondence should be addressed to Zamblé Bi Irié Abel Boli; bzia2011@yahoo.fr

Received 13 May 2020; Revised 20 May 2020; Accepted 27 July 2020; Published 6 August 2020

Academic Editor: Clemencia Chaves L. pez

Copyright @ 2020 Zamblé Bi Irié Abel Boli et al. This is an open access article distributed under the Creative Commons Attribution License, which permits unrestricted use, distribution, and reproduction in any medium, provided the original work is properly cited.

\begin{abstract}
Peanut paste produced in multipurpose mills is very often the site of choice for fungal contaminants that pose a major risk to consumers. The objective of this study is to evaluate the level of fungal contamination of peanut paste produced according to different moulding processes during storage. Thirty samples of peanut paste were produced from $60 \mathrm{~kg}$ of peanut pods according to three types of moulding (domestic moulding, artisanal moulding, and hygienic moulding) and then preserved for three months. These thirty samples were subjected to microbiological analysis using the conventional mould count method. The moisture content of the various peanut pastes was determined according to the AOAC method. Fungi were identified by using taxonomic schemes based on microscopic observation and culture appearance. Mould loads ranged from 0 to $6.4 .10^{2} \mathrm{cfu} / \mathrm{g} ; 91$ to $9.6 .10^{2} \mathrm{cfu} / \mathrm{g}$; and 0 to $4.6 .10^{2} \mathrm{cfu} / \mathrm{g}$, respectively, for domestic, artisanal, and hygienic mouldings during conservation. Moisture content increases during the conservation of peanut paste. It increases from 1.23 to $3.17 \%$ for domestic moulding, 1.30 to $3.20 \%$ for artisanal moulding, and 1.30 to $2.94 \%$ for hygienic moulding. Four fungal genera, namely, Aspergillus, Mucor, Absidia, and Penicillium and three species of Aspergillus including A. flavus, A. fumigatus and A. niger have been identified. The peanut paste produced from domestic and hygienic moulding is less contaminated during storage than that obtained in the artisanal way.
\end{abstract}

\section{Introduction}

Peanut is a staple food for the majority of people in subSaharan Africa $[1,2]$ and consumed in several forms, including seeds, oil, boiled, flour, cake, and paste [3, 4]. Peanut paste consumed in households is also marketed directly in markets. In Côte d'Ivoire, the control of the informal sector over the storage and marketing conditions of peanut paste production is mostly outside the control of the government. However, peanuts and their derivatives consumed in various forms are subject to contamination by pathogenic fungi throughout the production chain. The most frequent targets of these pathogenic fungi are cereals and oilseeds, particularly peanut. Peanut paste is produced in artisanal or semiartisanal production units and marketed directly in markets. Samples of peanut paste taken directly from markets in Abidjan contained various fungal genera, including Mucor, Alternaria, Helmintosporium, Geotrichum, Fusarium, Cladosporium, Penicillium, and Aspergillus, and mycotoxins, particularly aflatoxin B1 and ochratoxin A $[5,6]$. Studies conducted in several sub-Saharan African countries including Mali, Benin, Nigeria, Kenya, and Côte d'Ivoire have shown contamination of peanut seeds, oil, cake, and paste by pathogenic moulds [7-9].

Several mycotoxins including aflatoxins, ochratoxin A, fumonisins, zearalenone, patulin, and many others found in food products are synthesized by moulds [10]. Among all these mycotoxins, the International Agency for Research on Cancer reported in 2002 that aflatoxin B1 causes cancer in the liver, prostate, and other human organs, while ochratoxin $\mathrm{A}$ is highly carcinogenic to the kidney and liver. According to [11], the level of exposure to aflatoxin B1 of 
Ivorian consumers of peanut paste produced in multipurpose mills varies between $2.072 \mathrm{ng} / \mathrm{kg} / \mathrm{day}$ and $2.193 \mathrm{ng} / \mathrm{kg} /$ day and leads to a population at risk estimated between $10.1 \%$ and $15.6 \%$ compared to the tolerable daily intake of $1 \mathrm{ng} / \mathrm{kg} /$ day according to the statistical modelling of the @RISK software. The cancer risk is proven by considering the margin of exposure values for cancer which are well above the limit value of 10,000 . Thus, the application of good manufacturing practice for peanut paste is necessary in order to put healthy products on the market.

It is in this context that this study was carried out in order to evaluate the action of peanut paste manufacture according to three types of moulding on fungal contamination on the one hand and the variation of the fungal load during the conservation of the peanut pastes resulting from these different mouldings on the other hand.

\section{Materials and Methods}

The study material consisted of peanut seeds (Arachis hypogaea L.) (Figure 1) from which the peanut paste samples were produced (Figure 2). These peanut seeds were collected in the sub-prefecture of Gohitafla, central-western Côte d'Ivoire.

\subsection{Sampling of Peanut Seeds and Preparation of Peanut Paste.} Sixty kilograms of dried peanut pods were collected from a groundnut production area in Gohitafla locality, Côte d'Ivoire. The peanut pods were decorticated, and the resulting seeds were roasted and bleached. The bleached peanut seeds were divided into three equal parts, and each of the three parts was moulded differently. The first part was crushed in a mortar (domestic moulding). The second part was moulded under the usual conditions of use of a multipurpose mill (artisanal moulding), and the third part was moulded in a mill and disinfected with boiling water (hygienic moulding). The peanut paste from each part has been subdivided into 12 fractions of $200 \mathrm{~g}$ each. Three fractions of $200 \mathrm{~g}$ each from each part were taken and analysed as a control. The other nine parts of each type of moulding were packed in clean, covered containers. These samples were placed in a cooler containing ice and then transported and stored in three randomly selected stores of peanut paste vendors in the markets of three communes of Abidjan (Abobo, Adjamé, and Yopougon). Samples of each type of peanut paste were taken after one month, two months, and three months of storage. A total of 36 peanut paste samples were analysed.

\subsection{Determination of Moisture Content. The moisture} content was determined according to the method of AOAC (1990) which is based on the loss of mass of the sample in the oven at $105^{\circ} \mathrm{C}$ until a constant mass is obtained. Thus, $5 \mathrm{~g}$ of peanut paste was introduced into a glass capsule of known mass $\left(m_{0}\right)$. The capsule containing the sample of total mass $m_{1}$ has been placed in an oven (Memmert, Germany) which is set at $105 \pm 2^{\circ} \mathrm{C}$ for a period of 24 hours. After removing from the oven, the capsule was cooled in a desiccator. After

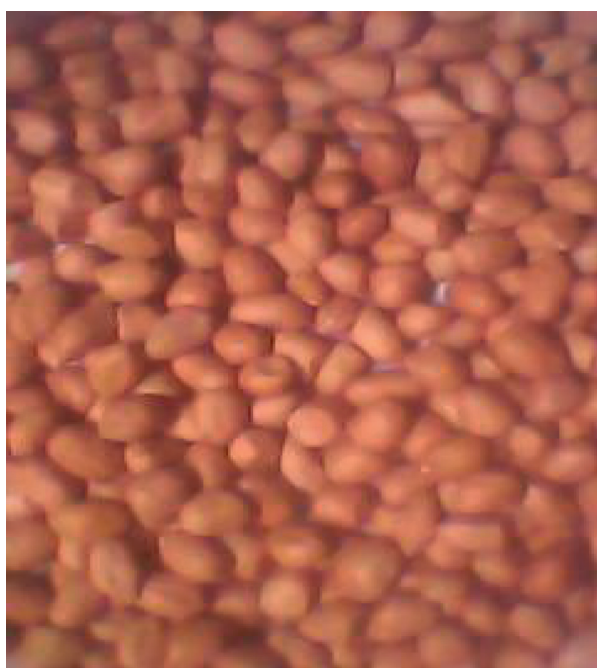

Figure 1: Peanut.

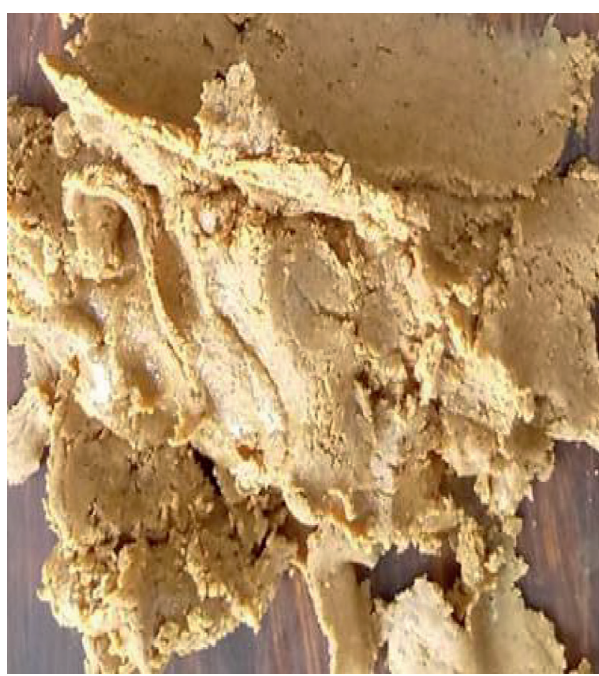

Figure 2: Peanut paste.

cooling, the whole content (sample + capsule) is weighed, and the mass is recorded. The operation is then repeated every 2 hours until a constant mass $\left(m_{2}\right)$ is obtained, and the moisture content is determined by the following formula:

$$
\text { moisture content }(\%)=\frac{\left(m_{1}-m_{2}\right)}{\left(m_{1}-m_{0}\right)} \times 100 .
$$

2.3. Mycological Analysis of Peanut Paste. The isolation of fungi was carried out according to the agar dilution method as described by [12]. Ten grams from each peanut butter sample were homogenized with $90 \mathrm{~mL}$ of buffer peptone water (AES Laboratory, France), and serial decimal dilutions $\left(10^{-1}\right.$ to $\left.10^{-4}\right)$ were performed. Fungal species were isolated on the semiselective Dichloran Rose Bengal Chloramphenicol (DRBC) agar (Biokar Diagnostics, France). The medium was poured into sterile Petri dish, and $0.1 \mathrm{~mL}$ of 
each sample suspension was spread-plated onto the DRBC agar in triplicate. The plates were incubated for 5 to 7 days at $25^{\circ} \mathrm{C}$. Fungal isolates were subcultured on Malt Extract and Czapek Yeast medium agars (Oxoid, UK) and incubated for 5 to 7 days at $25^{\circ} \mathrm{C}$ for purification. Fungi were identified by using taxonomic schemes based on microscopic observation and culture appearance including colonies' colours, texture, reverse colour, hyphae arrangement, conidia shape, and nature of spores [13]. Staining with methylene blue and fuchsine was used for the microscopic observation of mould on the objective $\times 40$. For the differentiation between $A s$ pergillus flavus colonies, AFPA agar (Oxoid, UK) supplemented with chloramphenicol was used. The total fungal count for each plate was expressed as colony-forming units per gram of sample (cfu/g). For each type of moulding, the fungal contaminant density was calculated based on the storage time. Thus, the density of a fungal contaminant for a given storage time is calculated by dividing the number of that particular contaminant by the number of all contaminants present for that storage time.

2.4. Statistical Analysis. All the analyses were performed in triplicate, and the data were analysed using EXCELL and STATISTICA 7.1 (StatSoft). Differences between means were evaluated by Duncan's test. A significance difference was established at $\alpha=0.05$.

\section{Results}

3.1. Changes in the Moisture Content of Peanut Paste during Storage. The changes in the moisture content of the peanut paste during storage according to the method of moulding are shown in Table 1 . On the first day, the moisture content was $1.23 \%$ for the domestic moulding samples and $1.3 \%$ for the artisanal and hygienic mouldings. During storage, the moisture content of the analysed samples ranged from 1.23 to $3.17 \%$ for the domestic moulding samples, from 1.3 to $3.2 \%$ and from 1.3 to $2.94 \%$ for the artisanal and hygienic mouldings, respectively.

\subsection{Loads and Fungal Profile of Peanut Paste during Storage}

3.2.1. Evolution of the Fungal Load. Table 2 shows the evolution of mould loads of peanut paste samples during storage according to the method of preparation. On the first day, an absence of mould was recorded in the samples of the domestic and hygienic mouldings. On the other hand, from the beginning (first day) to the end ( 3 months) of the shelf life, mould loads were recorded in all of the artisanal moulding samples analysed. Mould loads ranged from 0 to $6.4 .10^{2} \mathrm{cfu} / \mathrm{g}$; 91 to $9.6 .10^{2} \mathrm{cfu} / \mathrm{g}$; and 0 to $4.6 .10^{2} \mathrm{cfu} / \mathrm{g}$, respectively, for domestic, artisanal, and hygienic mouldings during storage. The highest loads were obtained with the samples of the artisanal moulding. A significant difference $(P<0.05)$ was observed between mould loads in the peanut paste samples regardless of the moulding method.
TABLE 1: Changes in the moisture content of peanut paste during storage according to the moulding method.

\begin{tabular}{lcccc}
\hline $\begin{array}{l}\text { Moulding } \\
\text { method }\end{array}$ & First day & 1 month & 2 months & 3 months \\
\hline $\begin{array}{l}\text { Domestic } \\
\text { moulding }\end{array}$ & $1.23 \pm 0.25^{\mathrm{a}}$ & $1.47 \pm 0.06^{\mathrm{a}}$ & $1.93 \pm 0.25^{\mathrm{a}}$ & $3.17 \pm 1.71^{\mathrm{a}}$ \\
$\begin{array}{l}\text { Artisan } \\
\text { moulding }\end{array}$ & $1.3 \pm 0.1^{\mathrm{a}}$ & $1.6 \pm 0.06^{\mathrm{a}}$ & $2.16 \pm 0.6^{\mathrm{ba}}$ & $3.2 \pm 1.71^{\mathrm{ba}}$ \\
$\begin{array}{l}\text { Hygienic } \\
\text { moulding }\end{array}$ & $1.3 \pm 0.1^{\mathrm{a}}$ & $1.5 \pm 0.1^{\mathrm{a}}$ & $1.7 \pm 0.3^{\mathrm{a}}$ & $2.94 \pm 0.1^{\mathrm{ba}}$ \\
\hline
\end{tabular}

The values assigned to the same letter are not significantly different at the $5 \%$ threshold according to Duncan's test.

\subsubsection{Fungal Profile of Peanut Paste during Storage by} Moulding Methods. Based on the identification keys, four fungal genera, namely, Mucor, Absidia, Penicillium, Aspergillus, and three species of Aspergillus were tentatively identified as A. flavus, A. fumigatus, and A. niger. Table 3 shows the evolution of these fungal contaminants identified in peanut paste samples during storage according to the type of moulding. On the first day, Mucor sp. was the only fungal contaminant isolated in the artisanal moulding samples. $A$. flavus and A. niger were the only species of Aspergillus that appeared in the samples analysed regardless of the type of moulding from the first month of storage. Penicillium sp. (domestic moulding), Absidia sp. and Penicillium sp. (artisanal moulding), and Mucor sp (hygienic moulding) which were absent in the first month of storage appeared from the second month onwards. All the same fungal contaminants from the second month appeared in the third month of storage. A. niger was the only species of Aspergillus that appeared in all samples tested regardless of the moulding type. The number of Aspergillus species increased from two (A. flavus and A. niger) at the first month to three (A. flavus, $A$. niger, and $A$. fumigatus) at the second month in the artisanal moulding samples. In the domestic moulding samples, the number of Aspergillus species increased from two (A. flavus and A. niger) in the second month of storage to one (A. niger) in the third month. $A$. niger was the only species isolated in the hygienic moulding samples.

\subsubsection{Density of Fungal Contaminant Isolation by Moulding} Type during Storage. Apart from the artisanal moulding paste, no fungal genus was identified on the first day in the other pastes according to the type of moulding. In the peanut paste of the domestic moulding, Aspergillus flavus was most identified after one month of storage; in the second month, the density was identical for A. flavus, A. niger, and Penicillium sp. (33\%). After three months of storage, an absence of A. flavus was observed (Table 4).

Concerning the peanut paste from the artisanal moulding, Mucor sp. and the species of A. flavus and A. niger were the most identified (33\%) in the second month of storage; Mucor sp. and A. niger were the most abundant $(25 \%)$ in the second month of storage. In the third month of storage, the most abundant fungal strains were Mucor sp., 
TABLE 2: Evolution of the mould load of peanut paste samples during storage according to the method of moulding.

\begin{tabular}{lcccc}
\hline \multirow{2}{*}{ Moulding method } & & \multicolumn{2}{c}{ Peanut paste mould load (cfu/g) } \\
& First day & 1 month & 2 months & 3 months \\
\hline Domestic moulding & - & $4.6 \pm 1.3 .10^{1 \mathrm{ba}}$ & $3.2 \pm 0.4 .10^{2 \mathrm{cb}}$ & $6.4 \pm 0.3 .10^{2 \mathrm{db}}$ \\
Artisan moulding & $91^{\mathrm{ab}}$ & $1.8 \pm 1.7 .10^{2 \mathrm{bc}}$ & $5.9 \pm 0.2 .10^{2 \mathrm{c}}$ & $9.6 \pm 0.1 .10^{2 \mathrm{dc}}$ \\
Hygienic moulding & - & $9.1 \pm 1.7 .10^{1 \mathrm{~b}}$ & $2.7 \pm 0.5 .10^{2 \mathrm{ca}}$ & \\
\hline
\end{tabular}

The values assigned to the same letter are not significantly different at the $5 \%$ threshold according to Duncan's test.

TABLE 3: Evolution of fungal contaminants identified in peanut paste samples during storage according to the type of moulding.

\begin{tabular}{|c|c|c|c|}
\hline \multirow{2}{*}{$\begin{array}{l}\text { Shelf life } \\
\text { (months) }\end{array}$} & \multicolumn{3}{|c|}{ Fungal genera } \\
\hline & Domestic moulding & Artisanal moulding & $\begin{array}{l}\text { Hygienic } \\
\text { moulding }\end{array}$ \\
\hline First day & ND & Mucor sp & ND \\
\hline 1 month & A. flavus & A. flavus, A. niger, Mucor sp. & A. niger \\
\hline 2 months & $\begin{array}{l}\text { A. flavus, A. niger, and } \\
\text { Penicillium sp. }\end{array}$ & $\begin{array}{l}\text { A. flavus, A. niger, A. fumigatus, Mucor sp., Absidia sp., and } \\
\text { Penicillium sp. }\end{array}$ & $\begin{array}{l}\text { A. niger, Mucor } \\
\text { sp }\end{array}$ \\
\hline 3 months & A. niger and Penicillium sp. & $\begin{array}{l}\text { A. flavus, A. niger, A. fumigatus, Mucor sp, Absidia sp, and } \\
\text { Penicillium sp. }\end{array}$ & $\begin{array}{l}\text { A. niger, Mucor } \\
\mathrm{sp}\end{array}$ \\
\hline
\end{tabular}

$\mathrm{ND}=$ Not detected; A. = Aspergillus.

TABle 4: Density of fungal contaminants.

\begin{tabular}{|c|c|c|c|c|c|}
\hline \multirow{2}{*}{ Moulding method } & \multirow{2}{*}{ Fungal contaminants } & \multicolumn{4}{|c|}{ Density (percentage) } \\
\hline & & First day & 1 month & 2 months & 3 months \\
\hline \multirow{3}{*}{ Domestic moulding } & A. flavus & 0 & 100 & 33 & 0 \\
\hline & A. niger & 0 & 0 & 33 & 50 \\
\hline & Penicillium sp. & 0 & 0 & 33 & 50 \\
\hline \multirow{6}{*}{ Artisanal moulding } & Mucor sp. & 100 & 33 & 25 & 20 \\
\hline & Absidia sp. & 0 & 0 & 12 & 10 \\
\hline & Penicillium sp. & 0 & 0 & 12 & 20 \\
\hline & A. flavus & 0 & 33 & 12 & 20 \\
\hline & A. niger & 0 & 33 & 25 & 20 \\
\hline & A. fumigatus & 0 & 0 & 12 & 10 \\
\hline \multirow{2}{*}{ Hygienic moulding } & Mucor sp. & 0 & 0 & 50 & 33 \\
\hline & A. niger & 0 & 100 & 50 & 67 \\
\hline
\end{tabular}

Penicillium sp., A. niger, and A. flavus with identical densities of $20 \%$.

In the peanut paste of the hygienic moulding, two fungal strains (A. niger, Mucor sp) were identified with a dominance of $A$. niger after 1 month (100\%) and 3 months (67\%) of storage. After two months of storage, the density (50\%) is identical for both fungal strains.

\section{Discussion}

The peanut paste obtained from the different types of moulding was kept in closed plastic containers. The structure of these containers does not allow the passage of water from the atmosphere into the product (peanut paste). Thus, the moisture content of the peanut paste samples varied somewhat during storage. The results obtained during the first two months of storage are consistent with those obtained $(1.8 \%)$ by [14] in the peanut paste used in Pakistan. Throughout the storage period, the moisture content of the samples remained below the critical value of $8 \%$, above which there may be abundant mould growth [15]. The low moisture content observed in the analysed samples on the first day could be related to good drying and/or roasting of the peanut seeds which are used to make peanut paste as reported by $[16,17]$. The technique used for this study measures evaporation at high temperature. Thus, what was detected as moisture after the first, second, and third month of storage could be due to volatile compounds from the enzymatic degradation of lipids or other compounds in the peanut paste. However, peanut pastes should be stored in a well-ventilated environment to avoid absorption of moisture from the air during storage. According to [18, 19], good air circulation in storage can prevent absorption of moisture from the immediate environment.

Peanut paste samples obtained from domestic and hygienic moulding are less loaded than those from artisanal moulding. Various food products are moulded in the artisanal mills. These different products after moulding leave residues in the mill. These nutrient-rich residues make the mill a favourable environment for the proliferation of 
microorganisms. Thus, after the formation of this microflora in the mill, all food passing through the mill is likely to be contaminated. With the hygienic moulding technique, the disinfection of the mill with boiling water before moulding allows the elimination of several microorganisms resulting in the reduction of mould loads in the peanut pastes from hygienic moulding compared to those from artisanal moulding. Peanut pastes from domestic moulding were likely contaminated with mortar and airborne mould spores. The results observed during the three months of storage regardless of the preparation method are consistent with those obtained by [7] in peanut cakes in Benin. These results are below the maximum level $\left(10^{4} \mathrm{cfu} / \mathrm{g}\right)$ recommended by the International Commission on Food Microbiology for peanut butters or pastes. These results could be explained by the good conditions under which the peanut paste is made, including seed sorting, domestic and hygienic moulding, clean and covered containers, and transportation of the peanut paste samples under the recommended conditions (cooler containing ice). Indeed, according to [20], practices such as sorting help reduce fungal contamination of products. In addition, Mutegi [21] reported that poor transportation conditions and marketing of peanut products or cakes can contribute to mould growth.

Fungal contaminants that have been identified in peanut paste samples analysed during storage are Mucor sp., Absidia sp., Penicillium sp., A. flavus, A. niger, and A. fumigatus. The results of this study are similar to the work of [8] who isolated most of these fungal strains, including A. flavus, A. parasiticus, A. tamarii, A. alliaceus, A. fumigatus, A. niger, Fusarium, Mucor sp., Penicillium sp., and Rhizopus sp., from peanut paste samples in the provinces of Kenya. The contaminants identified in this study belong to storage fungi that grow on food during storage [22, 23]. Aspergillus was the only fungal genus that were progressively isolated from all the samples analysed, regardless of the method of preparation. This is consistent with the work of several authors [24-26]. They reported the progressive increase of fungi of the genus Aspergillus during storage periods of peanuts and peanut products. The proliferation of Aspergillus in peanut paste during storage may be related to the use of carbohydrates, protein, fibre, and fat as growth-promoting nutrients [27, 28].

A. flavus and A. niger have been the main species isolated from peanut pastes during storage regardless of the method of preparation. This result is in accordance with the work of several authors who have also reported that $A$. flavus and $A$. niger are the major storage fungi $[29,30]$. The predominance of $A$. flavus and A. niger in analysed samples may pose a public health concern given their ability to produce mycotoxins [31, 32]. According to [33], A. flavus can produce aflatoxins. On the other hand, the authors of $[34,35]$ reported the production of ochratoxin A from A. niger in food.

The species Aspergillus flavus is absent after three months of storage in peanut paste from domestic moulding. This inhibition could be related to the action of bacteria. Indeed, Xianfeng [36] reported the antifungal action of several bacteria (Bacillus, Lactobacillus, Streptomyces etc.) on A. flavus. According to these same authors, A. niger has an inhibitory effect on the growth of A. flavus.

\section{Conclusion}

Peanut paste samples obtained from domestic and hygienic moulding are less susceptible to fungal growth during storage than those obtained from artisanal moulding. This study showed that samples of peanut paste produced from different moulding processes and subjected to storage are minimally contaminated with moulds such as Mucor sp., Absidia sp., Penicillium sp., and Aspergillus. The dominant contaminants belong to the genus Aspergillus, including species of A. flavus and A. niger. In addition, the presence of pathogenic fungi including A. flavus, A. niger, and Penicillium sp. is a health risk for consumers of peanut paste especially since these moulds are the potential producers of aflatoxin B1 and ochratoxin A in food. To ensure better quality of the peanut paste, owners of artisanal mills must necessarily do complete cleaning and disinfection of their mill after each moulding of the food product. Vendors must keep peanut paste in cold storage.

\section{Data Availability}

Data used to support the findings of this study are included within the article.

\section{Conflicts of Interest}

The authors declare that there are no conflicts of interest regarding the publication of this paper.

\section{Acknowledgments}

The authors would like to thank the peanut paste sellers in the communes where various samples were stored. This research was carried out at the Laboratory of Microbiology and Food Biotechnology of the University Nangui Abrogoua.

\section{References}

[1] C. M. Jolly, B. Bayard, and S. Vodouhe, "Risks of ingestion of aflatoxin-contaminated groundnuts in Benin: scale measurements, beliefs, and socioeconomic factors," Risk Analysis, vol. 29, no. 10, pp. 1395-1409, 2009.

[2] F.G. Honfo, K. Hell, N. Akissoe, R. A. M. Dossa, and J. D. Hounhouigan, "Diversity and nutritional value of foods consumed by children in two agro-ecological zones of Benin," African Journal of Food and Science Ressearch, vol. 4, pp. 184-191, 2010.

[3] S. A. Bankole, B. M. Ogunsanwo, and D. A. Eseigbe, "Aflatoxins in Nigerian dry-roasted groundnuts," Food Chemistry, vol. 89, no. 4, pp. 503-506, 2005.

[4] C. Keita, A. H. Babanaa, D. F. Traoré, A. H. Samaké, K. Faradjia, and A. Maïga, "Evaluation of the sanitary quality of peanut butters from Mali : identification and quantification of aflatoxins and pathogens," Scientific Journal of Microbiology, vol. 2, pp. 150-157, 2013.

[5] Z. A. Boli, L. T. Zoue, W. A. M. Alloue-Boraud, C. A. Kakou, and R. Koffi-Nevry, "Proximate composition and mycological characterization of peanut butter sold in retail markets of Abidjan (Côte d'Ivoire)," Journal of Applied Biosciences, vol. 72, pp. 5822-5829, 2013. 
[6] Z. A. Boli, L. T. Zoue, R. Koffi-Nevry, and M. Koussemon, "Fungal contamination and mycotoxin' occurrence in peanut butter marketed in Abidjan district (Côte d'Ivoire)," Food and Environment Safety, vol. 8, no. 3, pp. 267-275, 2014.

[7] S. E. Adjou, B. Yehouenou, C. M. Sossou, M. M. Soumanou, and C. A. Souza, "Occurrence of mycotoxins and associated mycoflora in peanut cake product (kulikuli) marketed in Benin," African Journal of Biotechnology, vol. 11, pp. 1435414360, 2012.

[8] J. W. Ndung'u, A. O. Makokha, C. A. Onyango et al., "Prevalence and potential for aflatoxin contamination in groundnuts and peanut butter from farmers and traders in Nairobi and Nyanza provinces of Kenya," Journal of Applied Biosciences, vol. 65, pp. 4922-4934, 2013.

[9] A. L. Manizan, M. Oplatowska-Stachowiak, I. Piro-Metayer et al., "Multi-mycotoxin determination in rice, maize and peanut products most consumed in Côte d'Ivoire by UHPLCMS/MS," Food Control, vol. 87, pp. 22-30, 2018.

[10] AFSSA, "Évaluation des risques liés à la présence de mycotoxines dans les chaînes alimentaires humaine et animale," Mars, AFSSA, Paris, France, Rapport Final, 2009.

[11] Z. Boli, L. Zoué, M. Koussemon, and R. Koffi-Nevry, "Low occurrence of mycotoxins in traditional peanut butter is associated with risk for consumers," European Journal of $\mathrm{Nu}$ trition \& Food Safety, vol. 7, no. 4, pp. 233-243, 2017.

[12] J. I. Pitt, A. D. Hocking, R. A. Samson, and A. D. King, "Recommended methods for mycological examination of foods," in Modern Methods in Food Mycology", R. A. Samson, A. D. Hocking, J. I. Pitt, and A. D. King, Eds., pp. 365-368, Elsevier, Amsterdam, Netherlands, 1992.

[13] K. Singh, J. C. Frisvad, U. Thrane, and S. B. Mathu, An Illustrated Manual on Identification of Some Seed Borne Aspergilli, Fusaria, Penicillia and Their Mycotoxins, p. 133, Danish Government, Institute of Seed Pathology, Heller Up, Denmark, 1991.

[14] J. Sadaf, A. Bibi, S. Raza, K. Waseem, M. S. Jilani, and G. Ullah, "Peanut butter incorporation as substitute for shortening in biscuits : composition and acceptability studies," International Food Research Journal, vol. 20, no. 5, pp. 3243-3247, 2013.

[15] C. B. N'Dédé, C. M. Jolly, S. D. Vodouhe, and P. E. Jolly, "Economic risks of aflatoxin contamination in marketing of peanut in Benin," Economics Research International, vol. 1, pp. 1-12, 2012.

[16] J. L. Knoden, L. Dufour, and J. Bindelle, "Fabrication de beurre de cacahuète," p. 14, Collection Manuels et Techniques, Brussels, Belgium, 2003.

[17] B. S. Kumar, S. R. Shankar, R. P. Vasanthi, K. M. Vishnuvardhan, and M. Purushotham, "Comparative physico-cheminal, proximate and mineral analysis on raw and roasted seeds of groundnut," Communications in Plant Sciences, vol. 3, no. 4, pp. 25-29, 2013.

[18] K. Hell and C. Mutegi, "Aflatoxin control and prevention strategies in key crops of Sub-Saharan Africa," African Journal of Microbiology Ressearch, vol. 5, pp. 459-466, 2011.

[19] C. K. Mutegi, J. M. Wagacha, M. E. Christie, J. Kimani, and L. Karanja, "Effect of storage conditions on quality and aflatoxin contamination of peanuts (Arachis hypogaea L.)," International Journal of AgriScience, vol. 3, no. 10, pp. 746-758, 2013.

[20] P. Fandohan, K. Hell, and W. F. "Marasas, "Food processing to reduce mycotoxins in Africa. Pre-and postharvest management of aflatoxin in maize"' Leslie Journal Food Bandyopadhyay, vol. 2, pp. 302-309, 2008.

[21] C. K. Mutegi, H. K. Ngugi, S. L. Hendriks, and R. B. Jones, "Prevalence and factors associated with aflatoxin contamination of peanuts from Western Kenya," International Journal of Food Microbiology, vol. 130, no. 1, pp. 27-34, 2009.

[22] A. E. Mohammed and A. Mohammed, "Seed borne fungi of peanut in Egypt. Pathogenecity and transmission," Pakistan Journal of Biological Sciences, vol. 4, no. 1, pp. 63-68, 2001.

[23] C. C. Egejuru, G. O. Ihejirika, and O. P. Obilo, "Levels of damage, associated organisms and transmission of seed-borne fungi of groundnut seeds grown in southeastern Nigeria," International Journal of Agriculture and Rural Developement, vol. 16, no. 1, pp. 1392-1403, 2013.

[24] R. E. Omer, L. Verhoef, P. Van't Veer et al., "Peanut butter intake, GSTM1 genotype and hepatocellular carcinoma a case-control study in Sudan," Cancer Causes and Control, vol. 12, no. 1, pp. 23-32, 2001.

[25] I. A. Saleemullah, A. Khalil, and H. Shah, "Aflatoxin contents of stored and artificially inoculated cereals and nuts," Food Chemistry, vol. 98, no. 4, pp. 699-703, 2006.

[26] J. M. Wagacha, C. K. Mutegi, M. E. Christie, L. W. Karanja, and J. Kimani, "Changes in fungal population and aflatoxin levels and assessment of major aflatoxin types in stored peanuts (Arachis hypogaea linnaeus)," Journal of Food Research, vol. 2, no. 5, pp. 10-23, 2013.

[27] E. D. Fagbohum and O. S. Faleye, "The nutritional and mycoflora changes during storage of groundnut (Arachis hypogea)," International Journal of Agronomy and Agricultural Research, vol. 2, no. 6, pp. 15-22, 2012.

[28] J. B. Ameer, B. Venudevan, and B. Jayanthi, "Storage Fungi in groundnut and the associate seed quality deterioration," Plant Pathology Journal, vol. 12, no. 3, pp. 127-134, 2013.

[29] M. S. Youssef, O. M. O. El-Maghraby, and Y. M. Ibrahim, "Mycobiota and Mycotoxins of Egyptian peanut (Arachis hypogeae L.) seeds," International Journal of Botany, vol. 4, no. 4, pp. 349-360, 2008.

[30] C. N. Ezekiel, M. Sulyok, D. A. Babalola, B. Warth, V. C. Ezekiel, and R. Krska, "Incidence and consumer awareness of toxigenic Aspergillus section Flavi and aflatoxin B1 in peanut cake from Nigeria," Food Control, vol. 30, no. 2, pp. 596-601, 2013.

[31] E. Krysinska-Traczyk, J. Perkowski, and J. Dutkiewicz, "Levels of fungi and mycotoxins in the samples of grain and grain dust collected from five various cereal crops in eastern Poland," Annals Agriculture Environmental and Medecine, vol. 14, no. 1, pp. 159-167, 2007.

[32] P. M. Diedhiou, R. Bandyopadhyay, J. Atehnkeng, and P. S. Ojiambo, "Aspergillus colonization and aflatoxin contamination of maize and sesame kernels in two agro-ecological zones in Senegal," Journal of Phytopathology, vol. 159, pp. 268-275, 2012.

[33] A. Pacheco and V. Scussel, "Aflatoxins evaluation on in-shell and shelled dry Brazil nuts for export analysed by LC-MS/MS2006 and 2007 harvests," World Mycotoxin Journal, vol. 2, no. 3, pp. 295-304, 2009.

[34] M. K. Saleemi, M. Z. Khan, A. Khan, and I. Javed, "Mycoflora of poultry feeds and mycotoxins producing potential of aspergillus species," Pakistan Journal Botany, vol. 42, no. 1, pp. 427-434, 2010.

[35] C. N. Ezekiel, M. Sulyok, B. Warth, A. C. Odebode, and R. Krska, "Natural occurrence of mycotoxins in peanut cake from Nigeria," Food Control, vol. 27, no. 2, pp. 338-342, 2012.

[36] R. Xianfeng, Z. Qi, Z. Wen, M. Jin, and L. Peiwu, "Control of Aflatoxigenic Molds by antagonistic microorganisms: inhibitory behaviors, bioactive compounds, related mechanisms, and influencing factors," Toxins, vol. 1224 pages, 2020. 